IRA-International Journal of Management \&

Social Sciences

ISSN 2455-2267; Vol.17, Issue 02 (Q.2 2021)

Pg. no. 29-36.

IRA Academico Research

\title{
Influence of Firm Size on Performance of Deposit Taking Savings and Credit Cooperative Societies in Nairobi County, Kenya
}

\author{
Evans Vidija Sagwa ${ }^{1}$, Appolonius Shitiabai Kembu ${ }^{2 \#}$ \\ ${ }^{1}$ Senior Lecturer, School of Business and Management Studies, Technical University of Kenya, \\ Kenya. \\ ${ }^{2}$ Lecturer, School of Business and Economics, Mount Kenya University, Kenya.
}

\#corresponding author

Type of Work: Peer Reviewed.

DOl: https://dx.doi.org/10.21013/jmss.v17.n2.p2

\section{How to cite this paper:}

Sagwa, E.V., Kembu, A.S. (2021). Influence of Firm Size on Performance of Deposit Taking Savings and Credit Cooperative Societies in Nairobi County, Kenya. IRA-International Journal of Management \& Social Sciences (ISSN 2455-2267), 17(2), 29-36. DOl: https://dx.doi.org/10.21013/jmss.v17.n2.p2

(C) IRA Academico Research.

(cc) EY-NC This work is licensed under a Creative Commons Attribution-NonCommercial 4.0 International License subject to a proper citation to the publication source of the work.

Disclaimer: The scholarly papers as reviewed and published by IRA Academico Research are the views and opinions of their respective authors and are not the views or opinions of IRA Academico Research. IRA Academico Research disclaims any harm or loss caused due to the published content to any party.

IRA Academico Research is an institutional publisher member of Publishers International Linking Association Inc. (PILA-CrossRef), USA. IRA Academico Research is an institutional signatory to the Budapest Open Access Initiative. Hungary advocating the open access of scientific and scholarly knowledge. IRA Academico Research is a registered content provider under Open Access Initiative Protocol for Metadata Harvesting (OAI-PMH).

The journal is indexed \& included in WorldCat Discovery Service (USA), CrossRef Metadata Search (USA), WorldCat (USA), OCLC (USA), Open J-Gate (India), EZB (Germany) Scilit (Switzerland), Airiti (China), Bielefeld Academic Search Engine (BASE) of Bielefeld University, Germany, PKP Index of Simon Fraser University, Canada. 


\section{ABSTRACT}

The Savings and Credit Cooperative Societies (Saccos) in Kenya have made a tremendous contribution to national development which is responsible for about $45 \%$ of Gross Domestic Product and $31 \%$ of national savings and deposits. Deposit Taking Saccos (DTSs) have enabled cooperative societies to diversify their products and services in a highly competitive market. Those who patronize the services of DTSs have options of accessing similar services from other service providers like commercial banks and non-banking financial institutions that may enjoy economies of scale due to their size. However, some of the DTSs may be small in size which makes it difficult for them to leverage on size for wider coverage of their catchment market. Guided by Human Capital Theory (HCT) and the Resource-Based View (RBV) as the theoretical framework. The purpose of this study was to examine firm size as an important influencing factor on organization performance. The study adopted a descriptive design. The study was a census of the 42 DTSs operating in Nairobi County, Kenya. The target respondents were Chief Executive Officers and Human Resource Managers in the DTSs. Data was collected from 39 respondents using a questionnaire that was tested for reliability and validity. Data was analyzed using descriptive and statistical techniques. Cross-tabulation of the number of employees and organizational performance was done. Chi-square tests were also conducted. The findings of the study indicate that the DTSs with the highest number of employees performed higher than those with fewer employees. These findings suggest that organizations should pay more attention to firm size and leverage on the optimum size for competitiveness in the market.

Keywords: Firm Size, Performance, Deposit-Taking Saccos (DTSs)

\section{INTRODUCTION}

The Cooperative Movement in Kenya is responsible for about 45\% of Gross Domestic Product and 31\% of national savings and deposits. Deposit Taking Saccos (DTSs) have enabled cooperative societies to diversify their products and services in a market that is highly competitive as key players in the realization of Kenya Vision 2030 (Ministry of State for Planning, National Development and Vision 2030, 2012). Those who patronize the services of DTSs have options of accessing similar services from other service providers like commercial banks and non-banking financial institutions that may enjoy economies of scale due to their size. However, some of the DTSs may be small in size which makes it difficult for them to leverage on size for wider coverage of their catchment market. Guided by the Resource-Based View (RBV) as the theoretical framework, the purpose of this study was to examine firm size as an important influencing factor on organization performance.

Organizational performance can be measured in various ways. These may include but not limited to shares growth rate, market share, productivity and profitability (Ichniowski et al, 1997). The shares growth rate is a ratio that measures the rate of change in shares from time to time or a specified period of time. The utilization of historical growth rates is one of the methods of estimating future growth. Market share is the percentage of a market, which may be defined in terms of either units or revenue, accounted for by a specific entity. Market share is a keyindicator of market competitiveness, that is, how well a firm is doing against its competitors.

Deposit Taking SACCOs play a major role in promoting a culture of thrift or saving and credit accessibility in the Kenyan economy. The DTSs are expected to maintain high standards of accounting, resource management and transparency in the management of business (GOK, 2010). They are also expected to adhere to strict guidelines in all their dealings and operations as they compete in a dynamic business environment that affects their performance. Deposit Taking SACCOs (DTSs) operating in Kenya in general and in Nairobi County in particular, have to compete in the marketplace with other banking and non-banking institutions to attract and retain a steady clientele. The licensed DTSs have encountered challenges in regard to their performance contrary to the expectations of the stakeholders who are shareholders in the main SACCO that originate the DTSs and others who include but are not limited to those who patronize the services provided by the DTSs. These firms are expected to increase their share growth rates, expand their market share, increase productivity and profitability, which have not been realized by some of the DTSs. Some of the underpinning factors that influence the performance of DTSs maybe their size. Hence the focus of the study that set out to shed light on the grey area of the effect of size on organization performance that perspective that had hitherto not been included in previous organization performance empirical studies on DTSs in Kenya. 
IRA-International Journal of Management \& Social Sciences

\section{Problem Statement}

In the current business environment, different organizations including those that are operating in the SACCO subsector are striving for ways and means of attaining and sustaining a competitive advantage over their competitors through the uniqueness of their human resources, size and operational systems. The size of an organization can affect its performance (Terziovski \& Samson, 2000) which can be manifested in terms of shares growth rate, market share, productivity and profitability attained by the organization.

Deposit Taking SACCOs compete in a dynamic business environment that affects their performance. The organizations have to determine the appropriate size for their optimum operation and competitiveness in their markets and areas of business. An organization can use its size to build an inimitable business that can assist an organization to provide goods and services that cannot be easily imitated by its competitors. Due to the liberalization of the market in Kenya, organizations are encountering challenges and are unable to operate effectively due to micro and macro-economic circumstances that are adversely affecting business (KNBS, 2016). The DTSs are grappling with reduced market business volumes, declining market share, low levels of productivity and reduced profitability. These challenges can be traced to the size of the DTSs, hence the need for the current study.

A previous study in Kenya by (Sagwa, 2014) on firms Nairobi Securities Exchange found out that though HRMP that were adopted by firms had a positive effect on performance, there were other factors that may account for firm performance. The relationship between size and organization performance was examined which had hitherto not been done on DTSs in Kenya. Hence the need for the current study, which set out to answer the question; what is the influence of size on organization performance. The research study sought to test the hypothesis: There is no significant relationship between firm size and performance of Deposit Taking Savings and Credit Cooperative Societies in Nairobi County, Kenya.

\section{The Objective of the Study}

The study sought to assess the influence of firm size on the performance of Deposit Taking Savings and Credit Cooperative Societies in Nairobi County, Kenya.

\section{Value of the Study}

The study intended to emphasize the importance that organizations should place pay on firm size in order to leverage on the optimum size for competitiveness in the market. The findings and recommendations of the study have potential implications for managers who are expected to formulate business policies and implement strategies that may be influenced by the size of their organizations.

\section{LITERATURE REVIEW}

\section{Theoretical Foundations of the Study}

The study was anchored in the Human Capital Theory (HCT) and the Resource-Based View (RBV) of the firm. The Human Capital Theory (HCT) according to Schultz (1961) provides a perspective that value addition by people within an organization can contribute to enhancing better organization performance. Human Capital Theory regards people as assets and not a cost within an organization. Human capital according to Bontis (1998) represents the human factor in the organization; the combined intelligence, skills and expertise that gives the organization its distinct character that sets it apart from other organizations. The HCT Theory emphasizes the added value that people can contribute to an organization. Boxall (1996) refers to this situation as one that confers 'human capital advantage' to an organization.

The resource based view of the firm (Barney, 1991) provides a key element such that if HRM systems are to create 
sustained competitive advantage, they must be difficult to imitate. The resource based view has been of common interest for management researchers and numerous writings could be found for the same (Sagwa, 2013). A resourcebased view of a firm explains its ability to deliver sustainable competitive advantage when resources are managed such that their outcomes cannot be imitated by competitors, which ultimately creates a competitive barrier (Smith and Rupp 2002). There is strong evidence that supports the RBV (Crook et al., 2008). Organizations can attain and achieve a sustained competitive advantage through their employees according to Barney (1991). This can be realized when an organization has a human resource pool that cannot be imitated or substituted by its rivals or competitors.

\section{Empirical Review of Literature}

The size of an organization can affect its performance (Terziovski \& Samson, 2000) which can be manifested in terms of shares growth rate, market share, productivity and profitability attained by the organization. Organizations have to position themselves appropriately to take advantage of the size. Organizations can maintain or create sustained competitive advantage through unique or rare, scarce, inimitable, and valuable internal resources (Barney, 1991). In order to enhance the performance of organizations human resources that fit the general resource based view idea has to be available (Paauwe, 1994; Boxall and Purcell, 2003).

(Truss, 2001; Guest and Peccei, 1994) are in favour of using multiple measures using a stakeholders' perspective of performance in order to do justice to the multiple goals of human resources in an organization. Empirical evidence that coherent and consistent systems or bundles automatically lead to higher performance (Gerhart, 2004; Guest, 1997). The resource based view has been a subject of much interest for management researchers and numerous writings could be found for same (Sagwa, 2013; Guthrie, 2001; Huselid, 1995; Barney, 1991)

\section{METHODOLOGY}

\section{Research Design}

The study adopted a descriptive research design. The descriptive research design ensured that nothing was manipulated within the variables of the study. As pointed out by Cooper \& Shindler (2006), a descriptive research design helps the researcher to collect data at one point in time and provides information about real aspects.

\section{The Population of the Study}

The study was a census of the 42 DTSs in Nairobi County, Kenya. The target respondents were Chief Executive Officers and Human Resource Managers or other managers of equivalent level in the DTSs. The population of the study comprised of all the 42 licensed Deposit Taking SACCOs in Nairobi County as listed in the Kenya Gazette (SASRA, 2015) as of $3^{\text {RD }}$ July 2015.

\section{Data Collection}

The researchers sought authority and obtained a Research Permit from the National Council for Science, Technology and Innovation (NACOSTI) to collect data. The researchers with the help of research assistants administered an Introduction Letter and the data collection instrument mainly through the drop and pick later method. Data was collected from 39 respondents using a questionnaire that was tested for reliability and validity.

\section{Test of Validity and Reliability}

A pre-test was done by administering the instrument to sixteen human resource managers conveniently selected managers to fill for evaluation of the statement items for relevance, meaning and clarity. Content validation was also done by dividing the instrument into several sections. Each section was checked carefully to ensure that it conveyed the necessary message and attracted the relevant feedback, as per the tested specific themes of the research objective and hypothesis. The Cronbach's Alpha coefficient was used to measure the internal consistency of the constructs. The alpha coefficient of 700 or above was used as an acceptable measure. 


\section{Data Analysis and Discussion}

\section{Demographic Profiling}

Demographic profiling of respondents and their respective institutions was done as indicated in Table 1.

Table 1: Demographic Information

\begin{tabular}{|c|c|c|c|c|c|}
\hline \multirow{2}{*}{\multicolumn{2}{|c|}{ Demographic Information }} & \multicolumn{3}{|c|}{ Ownership of SACCO } & \multirow{3}{*}{ Tota } \\
\hline & & \multirow[t]{2}{*}{ Kenyan } & \multirow[t]{2}{*}{ Foreign } & \multirow[t]{2}{*}{ Other } & \\
\hline \multirow{4}{*}{ Designation of respondent } & Chief Executive Officer & & & & \\
\hline & Manager & 7 & 0 & 0 & 7 \\
\hline & $\begin{array}{c}\text { Human Resource } \\
\text { Manager }\end{array}$ & 12 & 0 & 0 & 12 \\
\hline & Other Please Specify & 19 & 0 & 0 & 19 \\
\hline \multicolumn{2}{|c|}{ Total } & 39 & $\mathbf{0}$ & $\mathbf{0}$ & 39 \\
\hline \multirow{4}{*}{ Number of employees } & Up to 100 & 14 & 1 & 0 & 15 \\
\hline & 101 to 200 & 17 & 0 & 1 & 18 \\
\hline & 201 to 300 & 4 & 1 & 0 & 5 \\
\hline & 301 to 400 & 1 & 0 & 0 & 1 \\
\hline \multicolumn{2}{|c|}{ Total } & 36 & 2 & 1 & 39 \\
\hline \multirow{2}{*}{ Years of operation inKenya } & 10 Years \& below & 15 & 1 & 0 & 16 \\
\hline & 11 to 20 & 11 & 1 & 1 & 13 \\
\hline & 21 to 30 & 6 & 0 & 0 & 6 \\
\hline & 31 to 40 & 3 & 0 & 0 & 3 \\
\hline & Above 40 Years & 1 & 0 & 0 & 1 \\
\hline \multicolumn{2}{|c|}{ Total } & 36 & 2 & 1 & 39 \\
\hline \multirow{5}{*}{ Category of Sacco } & Teacher based Sacco & 3 & 0 & 0 & 3 \\
\hline & Government based Sacco & 13 & 0 & 0 & 13 \\
\hline & Farmers based Sacco & 3 & 0 & 0 & 3 \\
\hline & Community based Sacco & 10 & 0 & 0 & 10 \\
\hline & Others & 7 & 2 & 1 & 10 \\
\hline \multicolumn{2}{|c|}{ Total } & 36 & 2 & 1 & 39 \\
\hline
\end{tabular}

Source: Field Data (2016)

From the findings 7 respondents were managers, 12 were human resource manager while majority 19 were from other departments i.e. loan officers, liaison officers. This indicates that a majority of the respondents were designated as human resource managers to handle the human resource function. Such managers would be expected to have a wealth of knowledge in handling human resource issues. It will also be essential to point out that majority of the respondents 37 were Kenyans while only two were foreign. The findings imply that ownership of a listed company may have an influence on human resource management practices and firm performance. Table 1 also shows that 15 institutions have an employee population of up to 100 employees; 18 institutions had an employee population range of 101-200; five institutions had a population of the employee range of $201-300$, and only one institution had an employee range of $301-400$.

In the period they have been operating in the country, 16 firms have been in operation in the country for less than 10 years; 13 had operated for a period of between 11 to 20 years; 6 institutions have operated for 21-30 years; 3 firms 
IRA-International Journal of Management \& Social Sciences

had operated for 31-40 years; while 1 institution have operated for the last 40 years. The study was also interested in the categories of Sacco's depending on their scope of operation since inception. From the findings, 13 institutions were Government based Sacco, 10 were Community based Sacco, Farmers based Sacco in the study were three and the rest (10) were others, consisting of community-based and profit orientedinstitutions.

\section{Cross Tabulation on Number of Employees and Organizational Performance}

A cross tabulation was done to find out the joint frequency distribution of cases based on two or more categorical variables as indicated in Table 2.

Table 21: Cross Tabulation on Number of Employees and Organizational Performance

\begin{tabular}{|c|c|c|c|c|c|c|c|c|c|c|}
\hline & & \multicolumn{8}{|c|}{ Organizational Performance } & \multirow{2}{*}{$\begin{array}{l}\text { Mean } \\
\text { score }\end{array}$} \\
\hline & & 3.25 & 3.50 & 3.75 & 4.00 & 4.25 & 4.50 & 4.75 & 5.00 & \\
\hline \multirow{2}{*}{ Number of } & Up to 100 & 1 & 1 & 2 & 4 & 4 & 3 & 0 & 0 & 4.05 \\
\hline & 101 to 200 & 0 & 2 & 4 & 5 & 4 & 1 & 1 & 1 & 4.07 \\
\hline \multirow[t]{2}{*}{ employees } & 201 to 300 & 0 & 1 & 0 & 0 & 0 & 3 & 1 & 0 & 4.35 \\
\hline & 301 to 400 & 0 & 0 & 0 & 0 & 0 & 0 & 1 & 0 & 4.75 \\
\hline Total & & 1 & 4 & 6 & 9 & 8 & 7 & 3 & 1 & 4.305 \\
\hline
\end{tabular}

Source: Field Data (2016)

From the findings, SACCOs with a population of 301 to 400 portrayed a high level of association with firm performance. These were followed by institutions with employees of between 201 and 300; institutions with employees of 101 to 200 followed and the least association were the institutions with employees less than 100 which stood with a mean of 4.05 .

\section{Chi-Square Tests}

Chi-square tests were to ascertain whether or not the two variables are independent. If the variables are independent (have no relationship), then the results of the statistical test will be "non-significant" and we "are not able to reject the null hypothesis", meaning that we believe there is no relationship between the variables as indicated in Table 3 .

Table 3: Chi-Square Tests

\begin{tabular}{|c|c|c|c|}
\hline & Value & Df & Asymp. Sig. (2-sided) \\
\hline Pearson Chi-Square & $35.592^{\mathrm{a}}$ & 28 & .153 \\
Likelihood Ratio & 30.962 & 28 & .319 \\
Linear-by-Linear Association & .002 & 1 & .966 \\
N of Valid Cases & 39 & & \\
\hline
\end{tabular}

Source: Field Data (2016)

a. 40 cells $(100.0 \%)$ have an expected count less than 5 . The minimum expected count is .03 .

\section{Organizational Performance}

Organizational performance was measured using four items namely; sales growth rate, market share, productivity and profitability. As shown in Table 4, the respondents rated the perceived extent to which the questionnaire items regarding firm performance were applied. 
Table 4: Organizational Performance

\begin{tabular}{|c|c|c|}
\hline Items & Mean & Std Deviation \\
\hline $\begin{array}{c}\text { Compared to your competitors in the previous year, what is your } \\
\text { Sacco's shares growth rate }\end{array}$ & 4.0769 & .62343 \\
\hline $\begin{array}{c}\text { Compared to your competitors in the previous year, what is your } \\
\text { Sacco's market share percentage }\end{array}$ & 4.0256 & .62774 \\
\hline $\begin{array}{c}\text { Compared to the previous year, what is the level of employee } \\
\text { productivity in your Sacco }\end{array}$ & 4.2051 & .61471 \\
\hline $\begin{array}{c}\text { Compared to the previous year, what is the level of profitability of } \\
\text { your Sacco }\end{array}$ & 4.1538 & .70854 \\
\hline \multicolumn{2}{|c|}{ Overall mean= 4.12; Overall Cronbach's Alpha= 0.765 } \\
\hline
\end{tabular}

Source: Field Data (2016)

A 5 - point Likert type scale was used to collect the responses, where 5 indicated 'strongly agree' and 1 indicated 'strongly disagree,' while 3 was taken as the midpoint. A mean of 3 and above-represented agreement or favorable response with the given statement, and a mean of less than 3 denoted less favorable. The most significant factor was the statement that 'Compared to the previous year, what is the level of employee productivity in your Sacco' with a mean of 4.2051 and standard deviation of .61471, while the least significant factor was the statement on market share, with a mean of 4.0256 and standard deviation of .62774. However, the overall mean score for organizational performance was 4.12 and a Cronbach's Alpha of 0.765.

\section{CONCLUSION AND RECOMMENDATIONS}

\section{Conclusion}

The study concluded based on the findings that the DTSs with the highest number of employeesperformed higher than those with fewer employees.

\section{Recommendations}

Organizations should pay more attention to firm size and leverage on the optimum size for competitiveness in the market. The findings of the study have implications for managers who are expected to formulate policies and implement business strategies that may be influenced by the size of their organizations.

\section{ACKNOWLEDGEMENT}

This research was conducted under the Research Permit NACOSTI/P/15/3402/7631 issued by the National Council of Science, Technology and Innovation (NACOSTI) Nairobi, Kenya.

\section{References}

[1]. Barney, J. (1991). Firm resources and sustained competitive advantage. Journal ofManagement, 17, 99-120.

[2]. Bontis, N. (1998). Intellectual Capital: "An exploratory study that develops measures and models," Management Decisions, 36(2); 63-76.

[3]. Boxall, P. (1996). The strategic HRM debate and the resource-based view of the firm, Human Resource Journal, 6(3): 59-75

[4]. Coopers, D.R., and Schindler, P.S. (2006). Business research methods, $9^{\text {th }}$ Edition. Mac Grow - Hill. Publishing Co. Ltd. New Delhi. India.

[5]. Crook, T. R., Ketchen Jr., D. J., Combs, J. G., and Todd, S. Y. (2008). Strategic resources and performance: A 

meta-analysis. Strategic Management Journal; 29, 1141-1154.

[6]. Gerhart, B. 2004. Research on human resources and effectiveness: selected methodological challenges. Working paper presented at the International seminar on HRM: What's Next? Organized by the Erasmus University Rotterdam, June 2004.

[7]. Government of Kenya (GoK), Cooperative (Amendment) Act, 2010 Sacco Business

[8]. Guthrie, J.P. 2001. High-involvement work practices, turnover, and productivity: evidence from New Zealand. Academy of Management Journal, 44: 180-190.

[9]. Guest, D.E. (1997). Human resource management and performance: a review and research agenda. The International Journal of Human Resource Management, 8: 263- 276.

[10]. Guest, D.E. and Peccei, R. 1994. The nature and causes of effective human resource management. British Journal of Industrial Relations, 32: 219-241.

[11]. Huselid, M.A. 1995. The impact of human resource management practices on turnover, productivity, and corporate financial performance. Academy of Management Journal, 38: 635-672.

[12]. Ichniowski, C., Shaw, K. and Prennushi. G. (1997). The effects of human resource management practices on productivity: A study of steel finishing line. The American Economic Review, June.

[13]. Kenya National Bureau of Statistics (KNBS), Economic survey 2016, Popular Version, Herufi House, April 2016 ISBN 9966-767-52-5, http://www.knbs.or.ke

[14]. Ministry of State for Planning, National Development and Vision 2030, (2012), Kenya Vision 2030, http://www.vision2030.go.ke

[15]. Sagwa, E. V. (2013). Fundamentals of development and their applications to Kenya, Manifested Publishers, Nairobi, Kenya

[16]. Sagwa, E. V. (2014). Human resource management practices and performance of firms listed on the Nairobi Securities Exchange. Unpublished PhD thesis, University of Nairobi

[17]. SACCO Societies Regulatory Authority, (2015). Licensed deposit taking SACCOs, Kenya Gazette as of $3^{\text {rd }}$ July 2015, http://www.sasra.or.ke

[18]. Schultz, T, W. (1961). Investing in human capital. American Economic Review, 51, March, 1-17

[19]. Smith. M., Thorpe R. and Rupp. A. (2002). Management research: An introduction.London: Sage.

[20]. Terziovski, M and Samson, D (2000). The effect of company size on the relationship between TQM strategy and organizational performance, The TQM Magazine, Vol. 12 Issue: 144-1498, http://dx.doi.org/10.1108/09544780010318406

[21]. Truss, C. 2001. Complexities and controversies in linking HRM with organizational outcomes. Journal of Management Studies, 38(8): 1121-1149. 